about $10^{-9}$ gauss. The experimental method was only sensitive enough to show that no field so large as $10^{-4}$ gauss was produced.

${ }^{1}$ Babcock, Astrophys. J., 105, 105 (1947).

2Chapman and Bartels, "Geomagnetism"' (Oxford, 1940).

s Schuster, Proc. Phys. Soc., London, 24, 121 (1912).

- Brunt, Astr. Nach., 196, 169 (1913).

s Swann, J. Franklin Inst. (1923).

- Cowling, Mon. Not. Roy. Ast. Soc., 105, 166 (1945).

' Elsasser, Phys. Rev., 55, 489 (1939).

- Elsasser, Phys. Rev., 60, 876 (1941).

- Frenkel, C.R. Acad. Sci. U.S.S.R., 49, 98 (1945).

${ }^{10}$ Gurevich and Lebedinsky, C.R. Acad. Sci. U.S.S.R., 49, 92 (1945).

" Larmor, Brit. Assoc. Rept. (1919), 159.

${ }^{12}$ Cowling, Mon. Not. Roy. Ast. Soc., 94, 40 (1933).

13 Schuster, Brit. Assoc. Rept. (1891).

" Sutherland, Terr. Mag., 5, 73 (1900); 8, 49 (1903); 9. 167 (1904); 13, 155 (1908)

${ }^{15}$ Wilson, Proc. Roy. Soc., A, 104, 451 (1923).

${ }^{16}$ Angenheister, Phys. Z., 26, 307 (1925).

17 Schlomka, Gerlands Beitr. Geophys., 38, 357 (1933).

${ }^{18}$ Haalck, Z. Phys., 105, 81 (1937); Gerlands Beitr. Geophys., 52, 243 (1938).

19 Swann, Phil. Mag., 3, 1088 (1927).

${ }^{20}$ Swann and Longacre, J. Franklin Inst., 206, 421 (1928).

${ }^{21}$ Jeffries, Mon. Not. Roy. Ast. Soc., 84, 534 (1924); Mon. Not. Roy. Ast. Soc., Geophys. Supp., 4, 63 (1937).

${ }^{22}$ Eddington, "Internal Constitution of the Stars" (Cambridge, 1926)

${ }^{23}$ Cowling, Mon. Not. Roy. Ast. Soc., 96, 57 (1935).

${ }^{24}$ Blanch, Lowan, Marshak and Bethe, Astrophys. J., 94, 37 (1941).

${ }^{25}$ Marshak and Blanch, Astrophys. J., 104, 82 (1946).

28 Milne, "Thermodynamics of Stars"' (Berlin, 1930).

${ }^{27}$ Elvey, Astrophys. J., 71, 771 (1930).

28 Rosseland, "Theoretical Astrophysics" (Oxford, 1936), 202-215.

"Becker, "Sterne und Stern Systeme" (Leipzig, 1942).

${ }^{80}$ Chapman, Mon. Not. Roy. Ast. Soc., 108, 116 (1943).

"Thiessen, Ann. Astrophy8., 8, 101 (1946).

32 Struve, Astrophy8. J., 72, 1 (1930).

s2 Westgate, Astrophys. J., 78, 46 (1933); 79, 357 (1934).

"Jeans, "Astronomy and Cosmogony" (1928).

${ }^{35}$ Russell, Dugan, Stewart, "Astronomy” (Ginn, 1945).

so Kuiper, "Novae and White Dwarfs" (Herman, Paris, 1941)

${ }^{37}$ Chapman, Mon. Not. Roy. Ast. Soc., 89, 57 (1928).

${ }^{38}$ Pannekoek, Bull. Ast. Inst. Netherlands, No. 19 (1922).

"2o Rosseland, Mon. Not. Roy. Ast. Soc., 84, 720 (1924).

"Cowling, Mon. Not. Roy. Ast. Soc., 90, 140 (1929).

\section{BRITISH ECLIPSE EXPEDITION TO BRAZIL}

T $N$ consequence of the aeroplane disaster at Dakar in the early hours of April 13, the British expedition to observe the total eclipse of the sun of May 20 at Araxa in Brazil has been cancelled.

The programme approved by the Joint Permanent Eclipse Committee of the Royal Society and the Royal Astronomical Society comprised four items.

The profiles of the chromospheric lines were to be observed using a Michelson echelon grating. The apparatus devised provides for a succession of short exposures at several points of the sun's limb to study the variation of profile and intensity with height above the sun as the moon successively masks off the lower layers. Some indication was hoped for of transition from photospheric temperatures to the high excitation temperatures now attributed to the coronal regions.

The corona was to be photographed in its own green monochromatic radiation through a large aperture (13.5-cm.) Fabry-Perot étalon to gain information on internal motions or rotation and to determine the profile of the green line accurately, also with a view to temperature assessment. The plates of the étalon had a separation of just over $1 \mathrm{~mm}$. and were aluminized to give a resolving power of some 400,000. The coronal image would be crossed by ares of cireular fringes the displacement or distortion of which would reveal the motions. These two instruments were designed by Dr. J. A. Carroll, now deputy for research and development to Controller of the Navy and scientific adviser to the Board of Admiralty, during his occupancy of the chair of natural philosophy at Aberdeen.

In addition, it was planned to determine the darkening towards the limb by using one of the infra-red photo-cells, developed at the Admiralty Research Laboratory, with suitable recording gear.

Observations to measure solar radio noise at a frequency of about 60 megacycles/sec. were also planned with the collaboration of the War Office and Ministry of Supply, apparatus having been prepared by Dr. J. S. Hey and Major S. J. Parsons.

Dr. Carroll had been asked to take charge of the expedition, its organisation and preparation by the Joint Permanent Eclipse Committee, assisted by. Dr. A. Hunter from the Royal Observatory, Greenwich, and one or two others, depending on what could be organised in the time available. During the period of preparation, he succeeded Mr. A. P. Rowe in the ehief scientific post at the Admiralty, and it was impracticable for him to give the time required for preparation of, and participation in, the expedition as originally contemplated. The specialized nature of the equipment made assistance hard to find. Dr. Alan Baxter, who had been on Prof. Carroll's staff in Aberdeen, was familiar with it and had participated substantially in its design and development there for use in Omsk in 1936, but he had become a principal scientific officer in the Royal Naval Scientific Service. The Board of Admiralty took the view that, in the circumstances, it was reasonable that they should advance pure scientific research by making their scientific officers' services available to the expedition. The remaining expert optical member required for the team was Mr. J. H. Strong, of the Spectroscopy and Astrophysics Department of the Imperial College of Science and Technology.

During the last few months of 1946 and the first three of 1947, the equipment was assembled, modified and tested by this team in a room made available at the Admiralty Research Laboratory and with assistance from the Laboratory's workshops. The intention was that the gear and three observers, Dr. Baxter, Dr. Hunter and Mr. Strong, should proceed by sea in time to give them a clear month on the site, they being joined about ten days before the eclipse day by Dr. Carroll and Major Parsons. Various factors, among them the fuel crisis in Britain, caused the last ship which could be relied upon to reach Rio de Janeiro in time to be one due to sail on March 11. This was only known a few days beforehand, and it was barely possible to complete testing, dismantle all instruments, pack them and get them on board, particularly as the fuel cuts and the weather had seriously slowed up the later stages of the work. However, the gear, with the exception of the FabryPerot étalon and certain parts of an image rotator used in the echelon spectrograph, was dispatched, and arrangements made for the three observers to go out by air a month later. In attempting landing at Dakar while the airfield there was fog-bound, the aeroplane carrying the observers broke up, Dr. Baxter being killed instantaneously, Mr. Strong receiving injuries which at first were thought not dangerous but later proved fatal (see p. 667). Dr. Hunter escaped with severe cuts and abrasions. An emergency party 
was tentatively arranged to fly out and carry on if the apparatus with Dr. Baxter was intact, but on word being received that the étalon plates were smashed and the image rotator parts missing, it was clear that the optical observations must be abandoned; and since the radio observer was dependent on assistance and facilities to be provided from the rest of the expedition, that part of the programme had to be abandoned too.

\section{OBITUARIES}

\section{Dr. Alan Baxter and Mr. John H. Strong}

THE aeroplane disaster at Dakar on April 13 cost the lives of two young men of science, who were to take part in the observations of the total solar eclipse on May 20 (see p. 666).

In Dr. Baxter, the Royal Naval Scientific Service has lost one of its most valuable younger members. Born in 1910, he was educated at Manchester Central High School and the University of Manchester. $\mathrm{He}$ graduated with honours in mathematics and in physics, proceeded to research in microphotometry and X-rays under Prof. (now Sir Lawrence) Bragg, taking his M.Sc. in 1932 and a Ph.D. in 1935. In 1934 he joined the staff of the Natural Philosophy Department of the University of Aberdeen, later becoming a lecturer in physics. He had a conspicuous talent for perceiving the critical features of an experiment or proposed design of apparatus and a genius for simple investigation of essentials. This made him a very valuable member of the Admiralty scientific staff during the War. At Aberdeen he became interested in physical optics and astrophysics and carried out at a temporary observatory just outside the city of Aberdeen during the winters of 1937 and 1938 continuous spectrophotometric observations of the variable star Algol. The analysis of the results strongly suggested a more complex structure for Algol than a binary system; the advent of war prevented complete working out and publication of the results.

Baxter returned to Aberdeen for a time after the War, but found the Naval Scientific Service attractive to him and entered it as a permanent officer in 1946 . He married in 1937 and is survived by his wife and two young daughters. He was a very welcome colleague, liked and respected, and his premature loss is deeply regretted.

Mr. John Strong was born in 1924 and educated at the Latymer Upper School and the Imperial College of Science and Technology, South Kensington. He graduated with honours in physies in 1944 and was appointed a demonstrator in the Spectroscopy and Astrophysics Department under Prof. H. Dingle and Sir George Thomson. He was carrying out research on a new type of arc source for spectroscopic analysis and was measuring the temperatures of various regions of the arc by means of the cyanogen bands. He was interested in interferometry and in astrophysics, and the eclipse observations offered excellent experience in his chosen field of research, which fitted him to be a valuable member of the observing team; and the Imperial College gladly agreed to make his services available. He was keen, energetic, eager and quick to learn.

It is particularly regrettable that what should have been valuable experience for these young men, from both of whom substantial contributions to science could confidently be expected, should have ended so tragically.

J. A. Carrolit

\section{Mr. W. J. Bean, M.V.O., I.S.O.}

IT is with deep regret that we have to record the death of William Jackson Bean, formerly curator of the Royal Botanic Gardens, Kew, who was known to every cultivator of hardy trees and shrubs by his standard three-volume work, "Trees and Shrubs Hardy in the British Isles". His death occurred on April 19 after a rather protracted illness, when within a few weeks of his eighty-fourth year. Born on May 26,1863 , in a village at the foot of the Yorkshire Wold, near Malton, his love for plant life was inherited, as for three generations his forbears had functioned as nurserymen. He was educated at Holgate School, York, and at the age of sixteen entered the famous gardens at Belvoir Castle to receive his early training in horticulture. At twenty years of age he entered the Royal Botanic Gardens, Kew, as a student gardener, and was quickly earmarked for promotion. After serving as sub-foreman in the Palm House and Orchid Houses, he was appointed foreman of the Temperate House, a position he occupied for several years before being transferred to the Arboretum as foreman in $\mathbf{1 8 9 2 .}$

During all this time and for several succeeding years, Bean contributed many articles to the horticultural press, chiefly The Garden and The Gardeners" Chronicle, while in 1890 he collaborated with the late William Watson in the writing of a book on "Orchids, Their Culture and Management". He was appointed assistant curator at Kew in 1900, with special charge of the Arboretum and Arboretum Herbarium. During the next few years he was sent abroad on various missions connected with arboriculture, chiefly to the United States of America and countries of Southern Europe.

At the instance of the late Sir William T. ThiseltonDyer, Bean was entrusted with the preparation of a book descriptive of the Royal Botanic Gardens, Kew, and the work done there, which was published in 1908. It was in 1908 that he began serious work on the first two volumes of his great book on trees and shrubs, which took several years to complete; the third volume was prepared after his retirement. He also contributed many articles to the Kew Bulletin of Miscellaneous Information, mostly descriptive of his several journeys abroad and on new trees and shrubs. He was also a member of the committee appointed by King George $\mathrm{V}$ to advise on the trees in Windsor Great Park; was a member of the Floral Committee of the Royal Horticultural Society, and helped with the work of the Roads Beautifying Association from its inception.

Many honours came his way. In 1918 he was awarded the Victoria Medal of Honour by the Royal Horticultural Society, and in 1923 the same Society awarded him the Veitch Memorial Medal; later he was made an honorary member of the Society. In 1925, Bean was made a companion of the Imperial Service Order, and a few years later he received the membership of the Victorian Order for his work connected with the trees at Windsor. When Mr. Ernest Moore, the artist, was preparing for his exhibition of portraits of famous Yorkshiremen, Bean was selected as one of the number. The portrait was later purchased by Major Reginald Loder and presented 